\title{
FICHADO
}

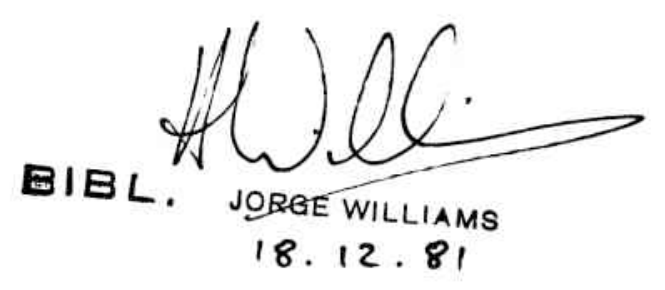

\section{Liolaemus pseudoanomalus, A Substitute Name for Liolaemus marmoratus (Burmeister 1861)}

Recent studies of the South American iguanid lizard genus Ctenoblepharis Tschudi 1845 have led to the conclusion that the ten species formerly referred to this genus probably form an artificial assemblage (Cei 1979a, 1979b, 1980). As a result Ctenoblepharis has been restricted to four species (adspersus, nigriceps, reichei, stolzmanni) from coastal Peru southward to the Atacama Plateau of Chile, and the six remaining species (anomalus, donosobarrios, jamesi, marmoratus, rabinoi, schmidti) from northern Chile and central and western Argentina have been placed in the genus Liolaemus Wiegmann 1835 (Cei 1979b, 1980). One of the latter forms was originally described as Leiosaurus marmoratus Burmeister 1861, and later referred by Muller (1928) to the genus Phrynosaura Werner 1907. Subsequently Phrynosaura was synonymized with Ctenoblepharis by Donoso-Barros (1971). With the allocation of this species of Liolaemus (Cei 1979b, 1980), Liolaemus marmoratus (Burmeister 1861) becomes a junior secondary homonym of Liolaemus marmoratus Gravenhorst 1838, a synonym of Liolaemus nitidus Wiegmann 1835 according to Boulenger (1885) and Peters and Donoso-Barros (1970). Accordingly, in the absence of any available junior synonym and in conformance with Art. 53 of the International Code of Zoological Nomenclature, the name Liolaemus pseudoanomalus is here proposed as a substitute name for 
Liolaemus marmoratus (Burmeister 1861). This name alludes to the form's apparent affinity with the sympatric species Liolaemus anomalus Koslowsky 1895. The nomenclatorial history of the species is as follows:

1861 Leiosaurus marmoratus Burmeister, Reise durch die La Plata Staaten, 2:524.

1928 Phrynosaura marmorata Muller, Zool. Anz., 77:63.

1971 Ctenoblepharis marmoratus Donoso-Barros, Herpetol. Review, 3:85.

1980 Liolaemus marmoratus Cei, J. Herpetol., 14:192.

I wish to acknowledge with thanks Richard Etheridge, San Diego State University, for his personal interest and criticism during my taxonomic studies of this difficult group of lizards.

\section{LITERATURE CITED}

Boulenger, G. A. 1885. Catalogue of the lizards in the British Museum. 2nd Ed., London 436.pp.

Burmeister, C. H. 1861. Peise durch die La Plata Staaten, Halle. 538 pp.

Cei, J. M. 1979a. Remarks on the South American iguanid lizard Liolaemus anomalus Koslowsky and the synonymy of Phrynosaura werneri Muller (Reptilia. Lacertilia. Iguanidae). J. Herpetol. 13:183-186.

- 1979b. A reassessment of the genus Ctenoblepharis (Reptilia. Lacertilia, Iguanidae) with a description of a new subspecies of Liolaemus multimaculatus trom western Argentina. J. Herpetol. 13:297-302.

$14: 192-193$.

Donoso-Barros, A. 1971. The genera Ctenoblepharis and Phrynosaura. Herpetol. Review 3:85.

Muller. L. 1928. Herpetologische Mitteilungen. 1-4. Uber die Typen von Gymnodactylus horridus Burm. und Leiosaurus marmoratus Burm. nebst Beschriebung einer neuen Art des Gattung Phrynosaura Werner. Zool. Anz. 77:61-84.

Peters, J. A. and R. Donoso-Barros. 1970. Catalogue of the Neotropical Squamata. II. Lizards and Amphisbaenians. Bull. U.S. Nat. Mus. 297:293 pp

J. M. CEI, Departamento Ciencias Naturales, Universidad National de Rio Cuarto, Cordoba Province, Argentina. Present address: Rancho Somuncura, Rua Fausto de Figeiredo, Birre, 2750. Cascais, Portugal. 